\title{
Classic Congenital Mesoblastic Nephroma
}

National Cancer Institute

\section{Source}

National Cancer Institute. Classic Congenital Mesoblastic Nephroma. NCI Thesaurus.

Code C39814.

A congenital mesoblastic nephroma characterized by the presence of interlacing fascicles of fibroblastic cells, low mitotic activity, and collagen formation. 